\title{
Review
}

\section{Thermic effect of food and sympathetic nervous system activity in humans}

\author{
L Tappy \\ Institute of Physiology, University of Lausanne, Lausanne, Switzerland
}

(Received 29 November 1995; accepted 28 May 1996)

\begin{abstract}
Summary - The intake of nutrients is known to increase energy expenditure. Measured thermic effects of nutrient are $0-3 \%$ for fat, $5-10 \%$ for carbohydrates and $20-30 \%$ for proteins. Stimulation of adenosine triphosphate (ATP) hydrolysis during intestinal absorption, initial metabolic steps and nutrient storage are responsible for this food thermic effect. The autonomic nervous system modulates the thermic effect of nutrients. Parasympathetic muscarinic antagonists reduce the thermic effect of orally administered nutrients, most likely by delaying gastric emptying and decreasing the amount of nutrient storage. Antagonists of the beta-adrenoreceptors decrease the thermic effect of glucose. The part of glucose induced thermogenesis which is eliminated by beta-adrenergic antagonists has been called 'facultative thermogenesis' and takes place, at least in part, in skeletal muscle. Insulin-induced stimulation of muscle sympathetic nerve activity may be involved in this facultative thermogenesis. The thermic effect of food is reduced in obese, insulin-resistant patients. The effect of thermogenesis represents about 50-150 kcal/day in such patients, and can explain only a minor part of their excess body weight. Defective thermogenesis may, however, contribute to weight gain, or impair weight loss in such patients.
\end{abstract}

energy expenditure / sympathetic nervous system / parasympathetic nervous system / obesity

Résumé - Effet thermique des aliments et activité nerveuse sympathique chez l'homme. L'administration de nutriments augmente les dépenses énergétiques de l'individu. L'effet thermique des graisses est de 0-3\%, celui des hydrates de carbone de 5-10\% et celui des protéines de $20-30 \%$. Cet effet thermique des aliments dépend principalement de l'hydrolyse d'ATP lors de leur absorption intestinale, de leur métabolisme ou de leur stockage. Le système nerveux autonome module l'effet thermique des aliments. Les antagonistes du système nerveux parasympathique (muscarinique) diminuent l'effet thermique des aliments en retardant la vidange gastrique et réduisant la quantité d'aliments stockée dans l'organisme. Les antagonistes $\beta$-adrénergiques diminuent l'effet thermique du glucose en abolissant la thermogenèse dite facultative. La stimulation par l'insuline de l'activité nerveuse sympathique musculaire pourrait jouer un rôle dans cette thermogenèse facultative. L'effet thermique des aliments est diminué chez les patients obèses résistant à linsuline. Cette diminution ne peut à elle seule expliquer la prise pondérale, mais peut contribuer à la difficulté qu'ont certains patients à perdre du poids.

dépense énergétique / système nerveux sympathique / système nerveux parasympathique / obésité 


\section{THERMIC EFFECT OF FOOD}

It has long been recognized that oral or parenteral administration of nutrients in healthy individuals is associated with a stimulation of energy expenditure. This increase over baseline of energy expenditure associated with feeding is referred to as the thermic effect of food (TEF). In humans, the measurement of energy expenditure is most frequently performed using indirect calorimetry (Jéquier and Felber, 1987). With this technique, the thermic effect of a nutrient or of a mixture of nutrients can be calculated in two different ways: either a bolus of the nutrient is administered orally or intravenously, and the energy expenditure is monitored until the nutrient has been absorbed and disposed of completely and energy expenditure has returned to baseline values. In these conditions, the thermic effect of the nutrient (expressed as a percentage of its energy content) can be expressed as the incremental area above baseline of energy expenditure divided by the energy content of the nutrient administered; or the nutrient can be administered continuously (either parenterally or enterally) until steady states in both energy expenditure and the plasma concentrations of the nutrient administered and of its metabolites are attained. In these conditions, the thermic effect of the nutrient can be expressed as the difference between energy expenditure observed after its administration and basal energy expenditure, divided by the rate of nutrient energy administered (Acheson, 1993).

Measured TEF are 5 to $10 \%$ of the caloric content of carbohydrates administered, 0 to $3 \%$ of that of lipids and 20 to $30 \%$ of that of proteins or amino acids (Flatt, 1978; Ravussin et al, 1983; Thiébaud et al, 1983a,b; Tappy and Jéquier, 1993). In healthy subjects over a $24 \mathrm{~h}$ period, TEF represents about $10 \%$ of the total amount of energy expended (Ravussin et al, 1986).

\section{MECHANISMS RESPONSIBLE FOR THE THERMIC EFFECT OF FOOD}

In rodents, energy expenditure can be dramatically increased by exposure to cold or carbohydrate overfeeding. In these conditions, the animals oxidize large amounts of fat and glucose in brown adipose cells (Himms-Hagen, 1995). These cells form a specialized thermoregulatory organ, in which oxidative phosphorylation can be uncoupled and nutrients oxidized to release heat without synthesis of adenosine triphosphate (ATP). This uncoupling of oxidative phosphorylation in brown adipose tissue of rodents can be triggered by the activation of the sympathetic nervous system. Although brown adipose tissue is present in normal newborn humans and in human adults under special circumstances (such as pheochromocytoma), there is no conclusive evidence that the brown adipose tissue plays an important role in the control of TEF in normal human adults (Astrup, 1986; Brundin and Wahren, 1991). Rather, it appears that TEF in adult humans is related to the stimulation of energy-requiring processes during the postprandial period. The intestinal absorption of nutrients, the initial steps of their metabolism and the storage of the absorbed, but not immediately oxidized nutrients, all require ATP hydrolysis, and therefore consume a certain amount of energy. As illustrated in figure 1, the net amount of energy provided by a nutrient which can be used by the organism to produce mechanical or chemical work is therefore equal to the total amount of ATP molecules synthesized upon oxidation of the nutrient minus the amount of ATP which has been hydrolyzed in the initial steps of the metabolism of the nutrient. Consequently, the ratio of ATP used in initial metabolic steps to ATP made upon complete oxidation of the riutrient can provide an index of the thermic effect of the nutrient. Furthermore, the amount of ATP 


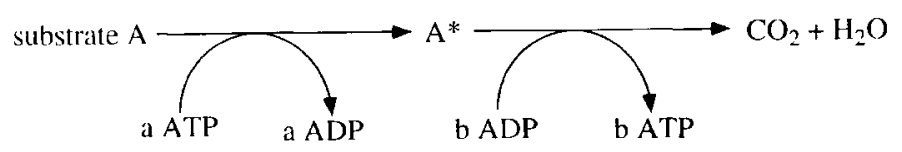

Fig 1. The thermic effect of a nutrient is related to the number of adenosine triphosphate (ATP) used in the initial steps of its metabolism. ADP: adenosine diphosphate. b: Total ATP synthesis $\approx$ total energy expenditure; a: ATP used for activation or storage of $A$ to $A^{*} ; b-a$ : net ATP available for energy-requiring processes; thermic effect of $A$ is proportional to $a / b$.

hydrolyzed when a given nutrient is metabolized varies according to the metabolic pathway used by the nutrient. Figure 2 illustrates the differences in initial ATP hydrolysis and the thermic effect of carbohydrate according to the metabolic pathway followed. After oral feeding, glucose is absorbed together with sodium in the duodenum using an energy-requiring transporter protein (SGLT1). One mol of ATP is hydrolyzed during absorption of $3 \mathrm{~mol}$ of glucose. To account for the energy cost of intestinal enzyme synthesis and gut motility, it is usually considered that $0.5 \mathrm{~mol}$ ATP are used for absorption of $1 \mathrm{~mol}$ glucose (Flatt, 1978). In this process, $0.5 \mathrm{~mol}$ ATP $/ \mathrm{mol}$ glucose is hydrolyzed. Subsequently, glucose oxidation and glycogen deposition will be the major fates of absorbed glucose. A third pathway of glucose disposal is de novo lipogenesis. This latter process is of little importance quanti- tatively in humans unless there is marked carbohydrate overfeeding (Hellerstein et al, 1991; Schwarz et al, 1995). In the initial steps of glucose oxidation, 2 mol ATP are hydrolyzed per mol glucose, one for the phosphorylation to glucose- 6 phosphate and the other for phosphorylation of fructose- 6 phosphate to fructose-1,6 diphosphate. On the other side of the balance, complete oxidation of fructose-1,6-diphosphate yields 38 mol of ATP synthesized from adenosine diphosphate (ADP). Therefore, the thermic effect of the directly oxidized glucose can be calculated as $(2.5 \mathrm{~mol}$ ATP used $) /(38$ mol ATP gained) $=6.6 \%($ fig 2$)$. The expected increase in energy expenditure associated with direct glucose oxidation, however, is considerably less than this value because oxidation of exogenous glucose replaces oxidation of endogenous glucose issued from hepatic glycogen hydrolysis, which also requires hydrolysis of ATP for its
Fig 2. Both glucose and fructose yield 38 adenosine triphosphate (ATP) synthesized from 38 adenosine diphosphate (ADP) upon complete oxidation. The number of ATP used prior to oxidation varies, however, according to the sugar considered and to the metabolic pathway followed prior to its oxidation, resulting in variable thermic effects.
ATP used in the initial steps of carbohydrate metabolisin

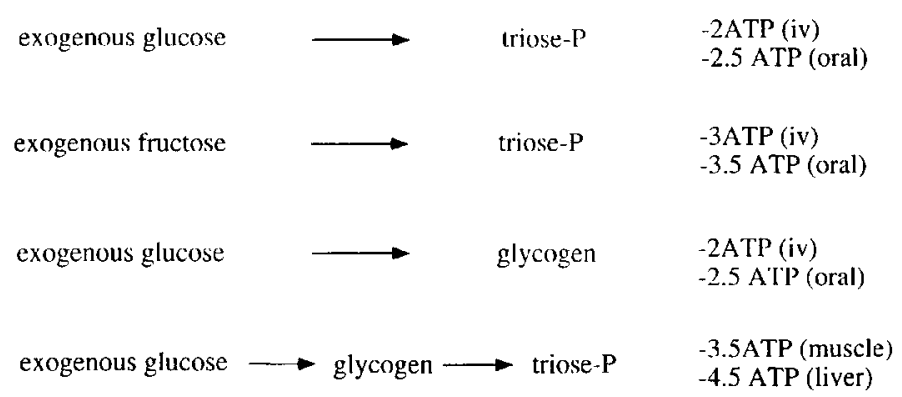


metabolism. Compared to the thermic effect of $75 \mathrm{~g}$ oral glucose $(6.5 \%)$, the thermic effect of fructose is substantially higher $(10.2 \%)$ (Tappy et al, 1986). This is explained by the fact that fructose metabolism requires the hydrolysis of one additional ATP for the phosphorylation of glyceraldehyde, which accounts for the increased thermic effect of this sugar (Tappy and Jéquier, 1993) (fig 2).

When glucose is converted into glycogen, 2.5 mol ATP are also consumed, $0.5 \mathrm{~mol}$ for glucose absorption, $1 \mathrm{~mol}$ for glucose- 6 phosphate synthesis and $1 \mathrm{~mol}$ for regeneration of uridine diphosphate (UDP) to uridine triphosphate (UTP) after uridyl diphospho-glucose synthesis. The thermic effect of glycogen synthesis from exogenous glucose is therefore about $2.5 / 38$ $=6.6 \%$. If glucose is released thereafter from muscle glycogen to be oxidized within the muscle, another mole of ATP will be required for the synthesis of fructose-1,6 diphosphate and the overall thermic effect will be $3.5 / 38=9.2 \%$. If glycogenolysis occurs in the liver and glucose is released into the systemic circulation, 2 additional moles of glucose will be hydrolyzed for the synthesis of fructose-1,6 diphosphate, bringing the thermic effect to about $11 \%$.

It can be seen then, that the amount of ATP used in metabolism can vary dramatically according to the metabolic pathway used. Changes in the rate of utilization of the endogenous substrate and the activation of energy requiring processes, such as glycogen synthesis, are believed to be responsible for the TEF.

\section{ROLE OF THE AUTONOMIC NERVOUS SYSTEM IN TEF}

A large number of studies have demonstrated that TEF can be modulated by pharmacological agents acting on the autonomic nervous system. Inhibition of the parasym- pathetic muscarinic receptors decreases the thermic effect of oral (Nacht et al, 1987), but not intravenous (Deriaz et al, 1989), glucose. This effect has been ascribed to a decreased glycogen synthesis due to a delay in gastric emptying and slower carbohydrate absorption (Schneeberger et al, 1991).

The beta-adrenergic receptors blockade decreases the thermic effect induced by infusions of glucose + insulin (Acheson et al, 1983). This part of the TEF of intravenous glucose which can be suppressed by betaadrenergic antagonists has been called 'facultative thermogenesis' (Acheson et al, 1984). Activation by the sympathetic nervous system of energy-requiring processes, such as the Cori cycle (Kusaka and Ui, 1977) and the lipolysis-reesterification of free fatty acids (Wolfe et al, 1987; Breitenstein et al, 1990), is likely to be involved in this facultative portion of TEF. However, it was shown that a 2 week treatment with beta-adrenergic antogonists did not alter the overall energy expenditure of healthy humans (Acheson et al, 1988). This suggested that the facultative thermogenesis of intravenous glucose may be related to sustained increases in plasma insulin concentrations.

The role of insulin per se in glucoseinduced thermogenesis has been investigated in several studies. Interestingly, insulin infusion has been reported to stimulate the sympathetic nervous system as demonstrated by an increase in plasma catecholamine concentrations (Rowe et al, 1981). More recently, it has been observed in healthy humans through in vivo microneurography of the lateral peroneal nerve that insulin specifically stimulates the sympathetic nerve fibers targeted to skeletal muscle (Anderson et al, 1991). This stimulation of muscle sympathetic nerve activity by insulin may be responsible for part of the facultative TEF, which has been suggested to take part predominantly in muscle (Astrup 
et al, 1985). The relationship between the insulin-induced activation of the sympathetic nervous system in skeletal muscle and facultative thermogenesis remains far from being clearly demonstrated. Fructose administered either orally (Tappy et al, 1986) or intravenously (Schwarz et al, 1992) markedly stimulates energy expenditure. Moreover, a substantial portion of this fructose thermic effect can be inhibited by betaadrenergic antagonists (Tappy et al, 1986; Schwarz et al, 1992). Fructose administered intravenously, however, does not elicit an increase in sympathetic muscle activity (Vollenweider et al, 1993), suggesting that other mechanisms are involved in the facultative thermogenesis of this sugar. In addition, the activation of muscle sympathetic activity by a lower body negative pressure (Brown et al, 1966; Scherrer et al, 1988) fails to stimulate basal energy expenditure (Tappy et al, 1995). This suggests that sympathetic muscle activity per se is not thermogenic. Interactions between actions of insulin and the sympathetic nervous system in muscle may be postulated to modify facultative, glucoseinduced thermogenesis.

\section{TEF IN OBESITY}

TEF has been extensively studied in the context of the pathogenesis of obesity. Several studies initially reported that the thermic effect of glucose is decreased in obese patients (reviewed in Tappy et al, 1991). Furthermore, it was observed that glucoseinduced thermogenesis is further depressed is post-obese patients (Schutz et al, 1984b). These results suggest that a defect in TEF may contribute to a positive energy balance and weight gain in pre-obese individuals. Other studies, however, markedly moderated these early conclusions. First, it was observed that a decreased TEF was not present in every obese patient. In fact, the studies that reported a normal TEF in obese patients are almost as common as those in which a decreased TEF was observed (D'Alessio et al, 1988). Second, it was noted that the decreased TEF of obese patients was observed after glucose feeding but not after fructose (Simonson et al, 1988) or amino acid administration (Tappy et al, 1993). Furthermore, the decrease in glucose-induced thermogenesis, when present in obese patients, was related to insulin resistance. During euglycemic, hyperinsulinemic clamps, overinfusion of insulin in obese subjects resulted in an overall glucose disposal similar to that observed in lean subjects and normalized glucoseinduced thermogenesis (Ravussin et al, 1985). Third, it was realized that the decreased TEF in obese patients represented only about 50-150 kcal/day (Schutz et al, 1984a). Individuals who gain weight increase both their fat mass and lean body mass. As a consequence of this increased body mass and fat-free mass, it can be estimated that $24 \mathrm{~h}$ energy expenditure increases by 20-25 kcal for each $\mathrm{kg}$ body weight gained due to an increase in both basal energy expenditure and the energy expended in physical activity (Ravussin et al, 1986; Owen, 1988). As a consequence, the decreased TEF of obese patients can account for a gain of $2-8 \mathrm{~kg}$, which is far less than the excess body weight of many obese individuals. This suggests that a defective TEF cannot be held as the major cause of weight gain in obese patients. It may nevertheless contribute to weight gain or the relapse of obesity after weight loss in some obese subjects.

\section{ACKNOWLEDGMENTS}

This work was supported by grants from the Swiss National Science Foundation (32-37247.93), the Foundation Professor Dr M Cloëtta and the Foundation Raymond Berger. 


\section{REFERENCES}

Acheson KJ (1993) Influence of autonomic nervous system on nutrient-induced thermogenesis in humans. Nutrition 9, 373-380

Acheson KJ, Jéquier E, Wahren J (1983) Influence of $\beta$-adrenergic blockade on glucose-induced thermogenesis in man. J Clin Invest 72, 981-986

Acheson KJ, Ravussin E, Wahren J (1984) Thermic effect of glucose in man: obligatory and facultative thermogenesis. J Clin Invest 74, 1572-1580

Acheson KJ, Ravussin E, Schoeller DA, Christin L, Bourquin L, Baertschi P, Danforth EJ, Jéquier $E$ (1988) Two week stimulation or blockade of the sympathetic nervous system in man; influence on body weight, body composition and twenty-four hour energy expenditure. Metabolism 37, 91-98

Anderson EA, Hoffman RP, Balon TW, Sinkey CA, Mark AL (1991) Hyperinsulinemia produces both sympathetic neural activation and vasolidation in normal humans. J Clin Invest 87, 2246-2252

Astrup A (1986) Thermogenesis in human brown adipose tissue and skeletal muscle induced by sympathomimetic stimulation. Acta Endocrinol 278 (suppl), 1-32

Astrup A, Bulow J, Madsen J, Christensen NJ (1985) Contribution of BAT and skeletal muscle to thermogenesis induced by ephedrine in man. Am J Physiol 248, E507-E515

Breitenstein E, Chioléro R, Jéquier E, Dayer P, Krupp S, Schutz $Y$ (1990) Effects of beta-blockade on energy metabolism following burns. Burns 16, 259-264

Brown E, Goei JS, Greenfield ADM, Plassaras GC (1966) Circulatory responses to simulated gravitational shifts of blood in man induced by exposure of the body below the iliac crests to subatmospheric pressure. $J$ Physiol 183, 607-627

Brundin T, Wahren J (1991) Influence of a mixed meal on splanchnic and interscapular energy expenditure in humans. Am J Physiol 260, E232-E237

D'Alessio EC, Kayle MA, Smalley KJ, Polansky M, Kendrick ZV, Owen LR, Bushman MC, Boden G, Owen OE (1988) Thermic effect of food in lean and obese men. J Clin Invest 81, 1781-1789

Deriaz $O$, Nacht $C$, Chioléro R, Jéquier $E$, Acheson $K$ (1989) The parasympathetic nervous system and the thermic effect of glucose/insulin infusions. Metabolism 38, 1082-1088

Flatt JP (1978) The biochemistry of energy expenditure. In: Recent Advances in Obesity Research. Newman Publishing, London, 211-228

Hellerstein MK, Christiansen M, Kaempfer S (1991) Measurement of de novo hepatic lipogenesis in humans using stable isotopes. $J$ Clin Invest 87,1841 1852
Himms-Hagen J (1995) Role of brown adipose tissue thermogenesis in control of thermoregulatory feeding in rats: a new hypothesis that links thermostatic and glucostatic hypothesis for control of food intake. Proc Soc Exp Biol Med 208, 159-169

Jéquier $E$, Felber $\mathrm{J}(1987)$ Indirect calorimetry. Baillère's Clin Endocrinol Metab 1, 911-935

Kusaka M, Ui M (1977) Activation of the Cori cycle by epinephrine. Am J Physiol 232, E145-E155

Nacht C, Christin L, Temler E, Chiolero R, Jéquier E, Acheson K (1987) Thermic effect of food: possible implication of the parasympathetic nervous system. Am J Physiol 253, E481-E488

Owen OE (1988) Resting metabolic requirements of men and women. Mayo Clin Proc 65, 503-510

Ravussin $E$, Acheson KJ, Vernet $O$, Danforth $E J$, Jéquier $E$ (1983) Thermic effect of infused glucose and insulin in man. Decreased response with increased insulin resistance in obesity and noninsulin-dependent diabetes mellitus. J Clin Invest 72, 893-902

Ravussin E, Acheson KJ, Vernet O, Danforth EJ, Jéquier $E$ (1985) Evidence that insulin resistance is responsible for the decreased thermic effect of glucose in human obesity. J Clin Invest 76, 1268-1273

Ravussin E, Lillioja S, Anderson TE, Clingtin L, Bogardus C (1986) Determinant of 24-hour energy expenditure in man: method and result using a respiratory chamber. J Clin Invest 78, 1568-1578

Rowe JW, Young JB, Minaker KL, Stevens AL, Pallota $J$, Landsberg $L$ (1981) Effects of insulin and glucose infusions on sympathetic nervous system activity in normal man. Diabetes 30, 219-225

Scherrer U, Floistrup Vissing S, Victor RG (1988) Effects of lower-body negative pressure on sympathetic nerve responses to static exercise in humans. $\mathrm{Cir}$ culation 78, 49-59

Schneeberger D, Tappy L, Temler E, Jeanprêtre N, Jéquier $E$ (1991) Effects of muscarinic blockade on the thermic effect of oral or intravenous carbohydrate. Eur J App/ Physio/ 63, 242-249

Schutz Y, Bessard T, Jéquier E (1984a) Diet-induced thermogenesis measured over a whole day in obese and nonobese women. Am J Clin Nutr 40, 542-552

Schutz Y, Golay A, Felber JP, Jéquier E (1984b) Decreased glucose-induced thermogenesis after weight loss in obese subjects: a predisposing factor for relapse of obesity. Am J Clin Nutr 39, 380387

Schwarz JM, Acheson KJ, Tappy L, Piolino V, Müller MJ, Felber JP, Jéquier $E$ (1992) Thermogenesis and fructose metabolism in humans. Am J Physiol 262, E591-E598

Schwarz JM, Neese RA, Turner S, Dare D, Hellerstein MK (1995) Short-term alterations in carbohydrate energy intake in humans. J Clin Invest 96, 27352743 
Simonson DC, Tappy L, Jéquier $E$, Felber JP, DeFronzo RA (1988) Normalization of carbohydrate-induced thermogenesis by fructose in insulin-resistant states. Am J Physiol 254, E201-E207

Tappy L, Jéquier $E$ (1993) Fructose and dietary thermogenesis. Am J Clin Nutr 58 (suppl), 766S-770S

Tappy L, Randin JP, Felber JP, Chioléro E, Simonson DC, Jéquier E, DeFronzo RA (1986) Comparison of thermogenesis effect of fructose and glucose in normal humans. Am J Physiol 250, E718-E724

Tappy L, Felber JP, Jéquier E (1991) Energy and substrate metabolism in obesity and postobese state. Diabetes Care 14, 1180-1188

Tappy L, Jéquier E, Acheson K (1993) Thermic effect of infused amino acids in healthy humans and in subjects with insulin resistance. Am J Clin Nutr 57 , 912-916

Tappy L, Girardet K, Schwaller N, Vollenweider L, Jéquier E, Nicod P, Scherrer U (1995) Metabolic effects of an increase of sympathetic activity in healthy humans. Int J Obesity 190, 419-422

Thiébaud D, Acheson K, Schutz Y, Felber JP, Golay A, DeFronzo RA, Jéquier $E$ (1983a) Stimulation of thermogenesis in men after combined glucose longchain triglyceride infusion. Am J Clin Nutr 37, 603-611

Thiébaud D, Schutz Y, Acheson K, Jacot E, DeFronzo R, Felber J, Jéquier $E$ (1983b) Energy cost of glucose storage in human subjects during glucose-insulin infusions. Am J Physiol 244, E-216-E221

Vollenweider $P$, Tappy L, Randin D, Schneiter $P$, Jéquier E, Nicod P, Scherrer U (1993) Differential effects of hyperinsulinemia and carbohydrate metabolism on sympathetic nerve activity and muscle blood flow in humans. J Clin Invest 92, 147-154

Wolfe $R$, Herndon D, Jahoor F, Miyoshi $H$, Wolfe M (1987) Effect of severe burn injury on substrate cycling by glucose and fatty acids. $N$ Engl $J$ Med 317, 403-408 